\title{
Appplication of a psychosocial/psychoanalytical and massive emotional multisensorial stimulation protocol in the recovery of alzheimer's cases
}

\author{
Luis Maria Sanchez*1, Agustina Leites ${ }^{1}$, Liliana Portillo1 ${ }^{1}$, Estefania Ferrari ${ }^{1}$, \\ Martinez Gisela ${ }^{1}$, Silvana Sastre ${ }^{1}$, Alejandra Jalife ${ }^{1}$, Juan Gomez Salgado ${ }^{2}$ and \\ William Pierce ${ }^{3}$
}

Address: ${ }^{1}$ Neurobiology, Uader Science and Technology Fac, C.del Uruguay, EERR, Argentine, ${ }^{2}$ Mental health nursing dpt., Huelva University, Espapa and ${ }^{3}$ Psychobiology Lab, Harvard University, USA

* Corresponding author

\author{
from International Society on Brain and Behaviour: 3rd International Congress on Brain and Behaviour \\ Thessaloniki, Greece. 28 November - 2 December 2007 \\ Published: 17 April 2008 \\ Annals of General Psychiatry 2008, 7(SuppI I):SIII doi:I0.II86/I744-859X-7-SI-SI I I
}

This abstract is available from: http://www.annals-general-psychiatry.com/content/7/SI/SI I I

(c) 2008 Sanchez et al.; licensee BioMed Central Ltd.

\section{Background}

These dementia begin associated with significant personal losses with coping deficit, producing familiar and social isolation behaviours and latter an attention fixation in their death's desire, that trigger the failures in the recognition mechanism associated to each one of the nine senses, that is essential for all activities of the dairy life and also to though, and then carry the well known behaviour abnormalities. When the sensorial recognition system's blockade of the sensorial channels is extended in time, its cause the stimulation blockade of the evolved neurons, then the loss of synapse and probably the neural death and its amyloid accumulation.

\section{Materials and methods}

The psychosocial/psychoanalytical multiemotional sensorial massive stimulation's protocol has been applied at present (June 2007) to 62 confirmly alzheimer's cases, from a 84 years old woman, to a 49 years old woman.

\section{Results}

Up to phase II the recovery were complete, between one week to three months, depending on family's participation and finantial support, and the persons return to the normality. The recovery of cases on phase III and IV were in some cases complete also, but in most of them partly and strange, like youthful state or child state also. In these III to IV phase's cases the recovery demand more than four months.

\section{Conclusions}

All the alzheimer's cases were quite different one of another, in their triggers, the dementia process and also in the recovery, suggesting clearly an individual matrix. The family interest and participation and its finantial support were the most important difficulties.

\section{Acknowledgements}

To Teresa Lin Lou, neurologist, Shangai/Montevideo, Magda Tieffenberg Tosteson, Harvard U., Boston/Buenos Aires and Ivor Kejthiani, University Finland.

\section{References}

I. Sanchez LM: From irresolute giblets-and-haslets to brain disintegration in alzheimer's cases: the psychosocial neural general theory. Conference> International Psicogeriatric Congress IPA, Lisboa; 2006. may

2. Sanchez de Machado LM, Rubano Martvnez MC, Garcva Camipa JD, et al.: Factores de comportamiento y dificit sensoriales identificatorios como predictores de la demencia tipo alzheimer. Rev Neurol 2007, 44:.

3. Sanchez LM, Gomez Salgado J, Molina Ruiz, Delmonte LB, Ferrari ED, Jalife MA, Leites MA, Martvnez GN, Portillo LA, y Sastre SR: Pruebas para la determinacion de fallo del sistema de reconocimiento asociado a la vision, audicion y tacto en diferentes 
casos de afectaciones de la consciencia en adultos mayores. Rev Psiogerontolog va 2006, 19:.

4. Sanchez LM, Cantero CR, Garcia JD, Florentin Ocampo BR, Garate Delgado LM: Development and validation of behavioral predictors for the beginning of the irreversible phase of Alzheimer's process: a prospective longitudinal study at South America. E J Cognitive and Brain Sciences 2005 [http://ejcbs.com/ table of content.html].

Publish with Bio Med Central and every scientist can read your work free of charge

"BioMed Central will be the most significant development for disseminating the results of biomedical research in our lifetime. " Sir Paul Nurse, Cancer Research UK

Your research papers will be:

- available free of charge to the entire biomedical community

- peer reviewed and published immediately upon acceptance

- cited in PubMed and archived on PubMed Central

- yours - you keep the copyright

Submit your manuscript here:

http://www.biomedcentral.com/info/publishing_adv.asp 